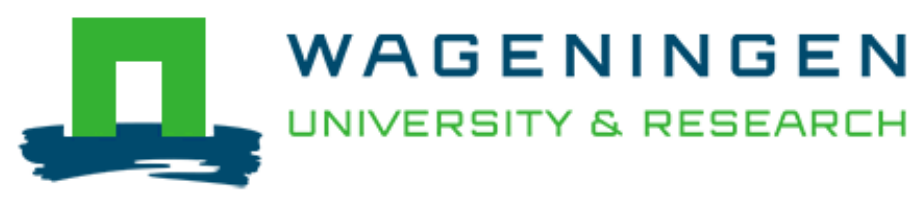

Foraging behaviour of wild impala (Aepyceros melampus) and Burchell's zebra (Equus burchelli) in relation to sward height

Mwasi, S. M., Heitkönig, I. M. A., Van Wieren, S. E., \& Prins, H. H. T.

This article is made publically available in the institutional repository of Wageningen University and Research, under article $25 \mathrm{fa}$ of the Dutch Copyright Act, also known as the Amendment Taverne.

Article $25 \mathrm{fa}$ states that the author of a short scientific work funded either wholly or partially by Dutch public funds is entitled to make that work publicly available for no consideration following a reasonable period of time after the work was first published, provided that clear reference is made to the source of the first publication of the work.

For questions regarding the public availability of this article, please contact openscience.library@wur.nl.

Please cite this publication as follows:

Mwasi, S. M., Heitkönig, I. M. A., Van Wieren, S. E., \& Prins, H. H. T. (2018). Foraging behaviour of wild impala (Aepyceros melampus) and Burchell's zebra (Equus burchelli) in relation to sward height. African Journal of Ecology, 56(2), 334341. https://doi.org/10.1111/aje.12459 


\title{
Foraging behaviour of wild impala (Aepyceros melampus) and Burchell's zebra (Equus burchelli) in relation to sward height
}

\author{
Shem M. Mwasi ${ }^{1}$ (D) | Ignas M. A. Heitkönig ${ }^{2}$ | Sipke E. Van Wieren ${ }^{2}$ | \\ Herbert H. T. Prins ${ }^{2}$
}

${ }^{1}$ School for Field Studies, Centre for Wildlife Management Studies, Nairobi, Kenya

${ }^{2}$ Resource Ecology Group, Department of Environmental Sciences, Wageningen University, Wageningen, The Netherlands

\section{Correspondence}

Shem M. Mwasi

Email: smwasi@fieldstudies.org

Funding information Netherlands Organisation for International Cooperation in Higher Education and

Wageningen University

\begin{abstract}
Foraging behaviour plays a key role in the interaction between herbivores and vegetation, their predominant food source. Understanding this interaction is crucial to providing information that is useful for conservation of herbivores. The objective of this study was to determine how sward height influences functional response and movement patterns of free ranging wild impala and zebra at the Kenya Wildlife Service Training Institute. The study was conducted for 3 months. Sward height is an important parameter that indicates how intensive a sward has been grazed and it influences intake rate through its effect on bite size. Bite size, instantaneous intake rate, specific mass intake rate and feeding station interval for impala and zebra increased with sward height. Sward height in combination with an animal's sex was found to have a profound effect on specific mass intake rate in impala. Zebra had a longer feeding station interval and lower stepping rate in tall swards compared to impala. Despite differences in their specific body mass and digestive strategies, impala and zebra maximized their intake rates in tall swards as a trade-off among the swards. Tall swards are therefore critical in the study area and should be protected from bush encroachment which is a persistent problem.
\end{abstract}

\section{Résumé}

Le comportement alimentaire joue un rôle primordial dans l'interaction entre les herbivores et la végétation, principale source de nourriture. II est crucial de bien comprendre cette interaction pour obtenir des informations utiles pour la conservation des herbivores. Cette étude avait pour objectif de déterminer comment la hauteur de la végétation influence les réponses fonctionnelles et le schéma des déplacements d'impalas et de zèbres circulant librement au Kenya Wildlife Service Training Institute. Cette étude a duré trois mois. La hauteur de la végétation est un paramètre important qui indique avec quelle intensité le sol est brouté, et elle influence le taux d'ingestion par son effet sur la taille des bouchées. Celle-ci, tout comme le taux d'ingestion instantané, le taux de consommation de masse spécifique et l'intervalle entre stations d'alimentation pour les impalas et les zèbres augmentaient avec la hauteur de la végétation. La hauteur de la végétation, combinée avec le sexe de l'animal, s'est avérée avoir un effet marqué sur le taux d'ingestion de masse spécifique chez les impalas. Les zèbres avaient un plus long intervalle entre stations de consommation et un rythme de marche plus lent dans les hautes herbes par rapport aux impalas. Malgré les différences de leurs masses corporelles et de leurs stratégies 
digestives spécifiques, les impalas et les zèbres optimisaient leur taux d'ingestion dans les plus hautes herbes comme un compromis entre les diverses hauteurs de végétation. La végétation plus haute est donc essentielle dans la zone étudiée et elle devrait être protégée contre l'envahissement de broussailles qui est un problème permanent.

KEYWORDS

feeding station interval, grass biomass, instantaneous intake rate, movement pattern, specific mass intake rate, sward height

\section{1 | INTRODUCTION}

Foraging behaviour is an important ecological process that relates a herbivore population to a plant community. Among wild ungulates, it is a dominant activity consuming about $40-60 \%$ of their daily time (Beekman \& Prins, 1989; Owen-Smith, 1982). Measuring the amount of forage consumed during foraging bouts contributes strongly to understanding foraging behaviour. Foraging behaviour is described in terms of its two basic components: functional response and movement pattern of an animal. Instantaneous intake rate (IIR) is achieved at feeding stations where food patches are exploited with minimum movement. Movement between feeding stations, the number of footsteps and time taken define the IIR of a particular foraging bout. In grazers, intake rate is a function of bite size (Black \& Kenny, 1984; Chacon \& Stobbs, 1976; Stobbs, 1973; Wikstrom, Robbins, Hanley, Spalinger, \& Parish, 1984), which in turn is influenced by sward (i.e., a piece of land covered with grass of the same species or a mixture of different species) characteristics (e.g., height, bulk density, biomass, grass nutritional status, age, spinosity and fibrousness) and an animal's own anatomy (e.g., body mass, digestive capacity and jaw dimensions). The response of intake rate to increasing bite size is governed by the interplay of handling and processing time in tall or dense swards but is a linear function of bite size in sparse swards. In a sparse sward, a large herbivore can consume a bite before encountering a succeeding one some distance way. However, in a dense sward, the herbivore has less time between bites to completely process one bite before moving to the preceding feeding station. In this case, the herbivore intake rate will be constrained by the handling time of the bite in the mouth before taking a new bite, and not by bite encounter (Spalinger \& Hobbs, 1992).

Movement in herbivores which involves taking one or several sets of footsteps occurs from one area to another for example, during foraging when an animal moves one or two steps in succession to another feeding station. During this kind of movement, foraging is not necessarily interrupted as the time taken per step is almost the same as that required to process a bite (Owen-Smith, Fryxell, \& Merrill, 2010). Movement also occurs for example, when an animal is searching for water or for resting sites or when escaping from predators. The overall movement rate while foraging can double or triple with a small proportional reduction in the time spent foraging within patches. A reduction in the quantity of forage results into an increase in movement rate by a herbivore. Novellie (1978) observed that movement by blesbok (Damaliscus dorcas) while feeding in a burnt grassland was double compared to when feeding in un-burnt grassland.

Movement pattern and intake rate are closely related foraging behaviour variables. Intake rate varies with the quantity (biomass) and quality (dry matter digestibility and crude protein) of forage in a feeding station. Feeding stations with a high forage biomass are utilized longer, therefore, resulting into a low movement rate compared to those with low forage biomass. Grass swards vary in biomass and quality depending on their phenological stage and height. Tall swards have a higher forage biomass but with a lower quality compared to short swards (Ombadi, Sudekum, \& Taube, 2001). In tall swards, movement rate is expected to be lower and intake rate higher than in short swards for large herbivores compared to small herbivores. This is because large herbivores with a higher specific body mass require a higher quantity of forage for their daily metabolic requirements than small ones (Clutton-Brook \& Harvey, 1983; Illius \& Gordon, 1987; Prins \& Olff, 1998).

Measuring movement pattern and intake rate of grazers in grass swards of different height are therefore critical to understanding their foraging behaviour. Here, we first describe experiments in which we measured the functional response variables of impala (Aepyceros melampus) and Burchell's zebra (Equus burchelli) with respect to sward height. Secondly, based on movement pattern variables, as zebra has a larger body mass than impala, we tested the prediction that its stepping rate would be lowest and feeding station interval (FSI) highest in tall swards, while for impala, stepping rate would be lowest and FSI highest in short swards.

According to the forage selection hypothesis by Main, Weckerly, and Bleich (1996), sexes segregate because sexual dimorphism leads to different energy requirements and food selection strategies between males and females. Total energy requirements of herbivores decrease with increasing body mass (weight ${ }^{0.75}$ ), therefore large herbivores require more gross daily energy than small ones (Illius \& Gordon, 1987). Small herbivores, however, require more energy per unit body mass than large ones, and therefore, their specific mass intake rate (SMIR) ( $\mathrm{g} / \mathrm{min}$ per $\mathrm{W}^{0.75}$ ) is expected to be higher than that of large herbivores when feeding on swards of similar quantity and quality. Large herbivores can survive on lower quality forage than 
small ones whose energy requirements per unit body mass are comparatively higher (Geist, 1974; Jarman, 1974). We used this principle to test the prediction that as impala is sexually dimorphic, with males having a larger body mass than females, SMIR increases in males from short to tall swards, while in females it decreases from short to tall swards.

\section{2 | MATERIALS AND METHODS}

\subsection{Study area}

The study was conducted in an open grassland within the Kenya Wildlife Service Training Institute, Main campus located about $80 \mathrm{~km}$ north-west of Nairobi, Kenya. The Institute comprises of three adjacent land units: Main campus (c. $2 \mathrm{~km}^{2}$ ), Annex (c. $0.2 \mathrm{~km}^{2}$ ) and "Game" farm (c. $4 \mathrm{~km}^{2}$ ). A wire mesh fence that has five passages to allow movement of wild animals to the "Game" farm and Annex surround the entire perimeter of Main campus. Vegetation communities found within the study area can broadly be grouped as follows:

1. Tarchonanthus bushland.

2. Euphorbia and cliff vegetation comprising mostly of Teclea simplicifolia and Euclea divinorum.

3. Open grassland.

A diversity of wild herbivores utilized the study area for foraging. They include impala, zebra, eland (Taurotragus oryx), warthog (Phacochoerus aethiopicus) and dikdik (Rhynchotragus kirkii).

\subsection{Field observations}

The study was conducted from January 1999 to March 1999 within a 1 ha study site selected in the open grassland where impala and zebra foraged consistently. Cynodon spp. and Eragrostis spp. dominated the grass swards within the site. Observations were made from $07.00 \mathrm{hr}-11.00 \mathrm{hr}$ in the morning and $14.00 \mathrm{hr}-18.00 \mathrm{hr}$ in the afternoon. These time periods coincided with peak daytime feeding activity by impala and zebra on the site. A single adult male or female impala or zebra whose identity was unknown was selected at random and its foraging behaviour observed for a maximum period of $5 \mathrm{~min}$. To minimize observational errors, we placed marked stakes adjacent to swards of predetermined height (short: $1-5 \mathrm{~cm}$, medium: 5-15 cm and tall: $\geq 15 \mathrm{~cm}$ ), to enable an observer on a $3 \mathrm{~m}$ high platform ascertain the exact sward height from a distance using a telescope. During the study, a total of 168 female and 115 male impala, and 298 zebra were observed. Female impala were observed for a total of $480.06 \mathrm{~min}$, male impala for $313.32 \mathrm{~min}$ while zebra were observed for 1,115.9 min.

The following activities were recorded while an animal foraged:

1. Number of bites: a bite occurred when movement of the head was observed.

while cropping grass
2. Number of chews: conspicuous jaw movements after biting indicated chewing.

3. Number of steps: an animal took a step when one of its forelegs moved forward.

4. Feeding station interval.

The following were distinguished: functional response variables (bite rate, chewing rate, instantaneous intake rate and SMIR) and movement pattern variables (stepping rate and $\mathrm{FSI}$ ).

\section{3 | Intake rate}

Ginnett and Dimment (1995) model was used to estimate IIR because it is difficult to measure IIR in the wild. The underlying principle behind the model is that mean dry matter intake rate of a herbivore is a function of its mean bite size. Accordingly, intake rate approaches an asymptotic maximum as bite rate increases and that biting and chewing are mutually exclusive activities. The model also divides a herbivore's per bite handling time into chewing and biting parameters that are independent of bite size.

$$
\text { i.e. } I I R=\frac{S}{(h+c E S)}
$$

where:

IIR = instantaneous intake rate $(\mathrm{g} / \mathrm{min})$

$\mathrm{S}=$ mean bite size $(\mathrm{g})$

$\mathrm{h}=$ mean time required to crop a bite from a patch (min per bite)

$\mathrm{c}=$ mean time of one chewing motion (min per chew)

$\mathrm{E}=$ mean number of chews allocated to each gram forage (chews/g).

Specific mass intake rate was obtained by dividing mean instantaneous intake rate of female and male impala or zebra by their respective metabolic weights. Given differences in digestive strategies between impala (a ruminant) and zebra (a nonruminant), we did not compare specific mass intake rate between them. However, we compared their movement pattern variables to gain insight into how they foraged on similar swards. Metabolic weights of 17.4 and $21.3 \mathrm{~kg}$ for female and male impala were calculated from mean live body weight of 45 and $59 \mathrm{~kg}$ for female and male impala, respectively (Haltenorth \& Diller, 1980; Skinner \& Smithers, 1990). 60 kg metabolic weight for zebra was calculated from a mean live body weight of $235 \mathrm{~kg}$ (Prins \& Olff, 1998). Bite size, that is, the mass in grams of plant tissue that is cropped at a single instant by a herbivore (Spalinger \& Hobbs, 1992) was indirectly determined using Parson, Thornley, Newman, and Penning (1994) model where bite size is the product of bulk density of grazed sward horizon and bite volume.

A field experiment was conducted to determine bulk density of the grazed horizon. $1 \times 1 \mathrm{~m}$ grass patches belonging to each of the three swards were selected at random. These were homogenous in structure, height and species composition. Each patch was divided into two equal parts, in one, pregrazed forage volume $\left(v_{i}\right)$ above $1 \mathrm{~cm}$ (assume un-grazable horizon below $1 \mathrm{~cm}$ height; Ungar \& Noy- 
Meir, 1988) was determined and all standing crop above this height clipped, dried and weighed. This served as the pregrazed biomass $\left(b_{i}\right)$. After a single grazing event in which the unclipped twin patch was partially defoliated by an individual impala or zebra, bite depth, that is, the mean vertical height in $\mathrm{cm}$ of grass that has been clipped in a single grazing event was calculated by measuring the difference between initial sward surface height and new sward surface height after grazing (Edwards, Parsons, Penning, \& Newman, 1995). The volume of forage left after a single grazing event served as the postgrazed volume $\left(v_{f}\right)$. After that, all the standing crop above $1 \mathrm{~cm}$ in the grazed patch was clipped, dried and weighed to determine the postgrazed biomass $\left(b_{f}\right)$. Mean bulk density of the grazed horizon of each sward height class was then computed as:

$$
\mathrm{BD}=\left(\frac{b_{i}-b_{f}}{v_{i}-v_{f}}\right)
$$

where:

$\mathrm{BD}=$ bulk density in $\mathrm{g} / \mathrm{cm}^{3}$

$b_{i}=$ initial (pregrazed) forage biomass in $g$

$b_{f}=$ final (postgrazed) forage biomass in $g$

$v_{i}=$ initial (pregrazed) forage volume in $\mathrm{cm}^{3}$

$v_{f}=$ final (postgrazed) forage volume in $\mathrm{cm}^{3}$

Bite volume was estimated as the product of bite area and bite depth (Parson et al., 1994).

Bite area was computed as the square of incisor breadth from skulls of each species from Naturalis, Leiden, the Netherlands and the Transvaal Museum, Pretoria, South Africa (Heitkönig, unpubl. data).

\subsection{Statistical analyses}

1-way ANOVA was used to test for differences in foraging behaviour variables among short, medium and tall swards for impala and zebra separately followed by a Tukey's HSD test to determine which variables differed significantly between the swards. The effect of sward height on movement pattern variables between impala and zebra was also tested using a 1-way ANOVA. Differences in foraging behaviour variables between female and male impala, in relation to sward height, were determined using a 2-way ANOVA. In cases where there was significant interaction between sex and sward height, a Tukey's HSD test was conducted. All the analyses were performed using SPSS version 8.0. (www.spss.com).

\section{RESULTS}

\section{1 | Bite size}

Bite size increased with sward height in impala from short $(0.14 \mathrm{~g})$ to tall $(0.27 \mathrm{~g})$ in female impala, $0.15-0.3 \mathrm{~g}$ in male impala, and from 0.68-1.8 $\mathrm{g}$ in zebra (Table 1). Therefore, zebra had approximately four- and fivefold larger bite sizes compared to impala in short and tall swards, respectively.

\subsection{Effect of sward height on foraging behaviour variables in impala and zebra}

For impala, bite rate decreased with sward height from 25 bites/min in short swards to 17.6 in tall swards. Chewing rate increased from 23 chews/min in short swards to 40 in tall swards, IIR from $1.8 \mathrm{~g} /$ min in short swards to 2.7 in tall swards and SMIR from $0.06 \mathrm{~g} / \mathrm{min}$ per $\mathrm{W}^{0.75}$ in short swards to 0.16 in tall swards. Bite rate, chewing rate, IIR and SMIR differed significantly among the three heights in impala (Table 2). A Tukey's HSD test found the following: that in impala, bite rate was significantly higher in short $(p=.047)$ and medium swards ( $p=.014)$ than in tall swards; chewing rate was significantly lower in short swards $(p=.030)$ than in medium swards; lower IIR in short swards $(p=.011)$ compared to medium swards and lower in medium compared to tall swards $(p=.045)$; specific mass intake rate was significantly lower in short swards $(p=.025)$ than in medium swards and in tall swards $(p=.007)$. In zebra, bite rate decreased from tall (20.3) to short (10.6) swards and differed significantly among the three swards. A significant increase from short to tall swards in IIR (7-9.7), and SMIR (0.12-0.16) respectively, was observed in zebra (Table 2). A Tukey's HSD test found that bite rate was significantly higher in short swards $(p=.037)$ compared to medium swards; IIR was significantly higher in tall swards ( $p=.001)$ compared to short swards, and SMIR was significantly higher in tall swards $(p=.028)$ compared to short swards. Impala had a significantly higher stepping rate $(4.1 \mathrm{steps} / \mathrm{min}$ in short to 3.6 in tall swards) compared to zebra (2.7 in short swards to 1.8 in tall swards), while FSI for zebra was significantly longer (43.4 s in short to 54.9 in tall swards) than for impala (20.5 in short to 33.2 in tall swards) (Table 3).

\subsection{Effect of sward height and sex on foraging behaviour variables in impala}

Female impala had a higher chewing rate in short swards (27.1) compared to male (16.8), while in medium and tall swards, males had a higher chewing rate. Specific mass intake rate increased with sward height in both sexes, with females having a lower SMIR (0.05) than males (0.09) in short swards, while in tall swards, females had a higher SMIR (0.18) compared to males (0.12) (Table 4).

A Tukey's HSD test on significant interactions from the 2-way ANOVA found that between male and female impala, there was a significant difference in chewing rate among all the three swards $(p=.000)$; in SMIR between short and medium swards $(p=.050)$ and between medium and tall swards $(p=.000)$.

Stepping rate in female impala increased from short (3.3) to tall swards (3.7), while in males it decreased from short (5.4) to tall swards (3.2). In females, FSI increased with sward height from short (24.1) to medium swards (31.8) but decreased in tall swards (19.6), while in males it decreased from short (14.8) to medium swards (11.2) but increased in tall swards (55.1) (Table 4). A Tukey's HSD test found that between male and female impala, there was a significant difference in stepping rate between short and medium swards 
$(p=.000)$ and between short and tall swards $(p=.000)$ and in FSI between short and tall swards $(p=.017)$ and between medium and tall swards $(p=.000)$.

\section{4 | DISCUSSION}

\section{1 | Foraging behaviour variables}

Okello, Wishitemi, and Muhoro (2002) estimated 0.78 and $1.93 \mathrm{~g}$ as bite size for impala and zebra respectively, and 27.28 and $48.76 \mathrm{~g} /$ min as IIR for impala and zebra respectively in the study area. This study estimated a maximum bite size and IIR of $0.3 \mathrm{~g}$ and $2.7 \mathrm{~g} / \mathrm{min}$ respectively for impala. Here, bite size was almost half and IIR ten times lower than in Okello et al. (2002). These differences are due to the studies being conducted during periods with different grass sward heights dominating in the area. Impala and zebra had smaller bites during this study because most swards were short and medium due to low rainfall. Smaller bites require more frequency of chewing which results into a decline in intake rate as observed in this study.
Okello et al. (2002) study was conducted during the peak of the rain season when taller swards were dominant allowing a bigger bite size and subsequently a higher intake rate in impala. Bite size is primarily influenced by a plant's growth phase, its leaf/grass blade ratio, fibre content and morphology, which are predominately influenced by rain in the study area. Bite size of zebra in tall swards was similar to Okello et al. (2002); however, IIR was almost 25 times lower. This again could be attributed to grass swards being predominately taller during Okello et al. (2002) study thus allowing a higher IIR by zebra.

\subsection{Specific mass intake rate and grass sward height}

Impala had its highest SMIR in tall swards. Lowest SMIR observed in short swards could be attributed to their low grass biomass. Considering that this study was conducted during low rainfall when grass production was not at its peak, short swards despite being of higher quality than tall ones did not have adequate grass biomass to meet impala daily maintenance requirements. Indeed, from our findings,

TABLE 1 Estimates of mean bite size using Parson et al. (1994) model

\begin{tabular}{|c|c|c|c|c|c|c|c|}
\hline Species & Sward & $\begin{array}{l}\text { Mean bulk } \\
\text { density }\left(\mathrm{g} / \mathrm{cm}^{3}\right)\end{array}$ & $\begin{array}{l}\text { Mean incisor } \\
\text { breadth }(\mathrm{cm})\end{array}$ & $\begin{array}{l}\text { Mean bite } \\
\text { area }\left(\mathrm{cm}^{2}\right)\end{array}$ & $\begin{array}{l}\text { Mean bite } \\
\text { depth }(\mathrm{cm})\end{array}$ & $\begin{array}{l}\text { Estimated bite } \\
\text { volume }\left(\mathrm{cm}^{3}\right)\end{array}$ & $\begin{array}{l}\text { Bite size (g) } \\
\text { mean } \pm \mathrm{Cl}(n)\end{array}$ \\
\hline \multirow[t]{2}{*}{ Female impala } & Short & 0.0015 & \multirow[t]{2}{*}{3.03} & \multirow[t]{2}{*}{9.18} & 1 & 9.18 & $0.14 \pm 0.01$ \\
\hline & Tall & 0.002 & & & 15 & 137.7 & $0.27 \pm 0.12(31)$ \\
\hline Male impala & Short & 0.0013 & 3.34 & 11.16 & 1 & 11.16 & $0.15 \pm 0.01$ (38) \\
\hline \multirow[t]{3}{*}{ Zebra } & Short & 0.0086 & \multirow[t]{3}{*}{6.3} & \multirow[t]{3}{*}{39.69} & 2 & 79.38 & $0.68 \pm 0.13(28)$ \\
\hline & Medium & 0.003 & & & 11 & 436.6 & $1.30 \pm 0.15$ (31) \\
\hline & Tall & 0.0023 & & & 20 & 793.8 & $1.80 \pm 0.16(40)$ \\
\hline
\end{tabular}

TAB LE 2 Variation in foraging behaviour variables of impala and zebra grazing on short, medium and tall swards. Sexes have been combined

\begin{tabular}{|c|c|c|c|c|c|}
\hline & Variable & $\begin{array}{l}\text { Short sward } \\
\text { Mean } \pm \mathrm{Cl}(n)\end{array}$ & $\begin{array}{l}\text { Medium sward } \\
\text { Mean } \pm \mathrm{Cl}(n)\end{array}$ & $\begin{array}{l}\text { Tall sward } \\
\text { Mean } \pm \mathrm{Cl}(n)\end{array}$ & F-ratio \\
\hline \multirow[t]{6}{*}{ Impala } & Bites/min & $25 \pm 2.4(45)$ & $20.4 \pm 0.89(105)$ & $17.6 \pm 1.1(66)$ & $11.08^{* * *}$ \\
\hline & Chews/min & $23 \pm 5.3(45)$ & $39.8 \pm 3.1(100)$ & $40 \pm 3.1(64)$ & $29.56^{* * *}$ \\
\hline & IIR & $1.8 \pm 0.18(45)$ & $2.4 \pm 0.12(100)$ & $2.7 \pm 0.16(64)$ & $28.11^{* * *}$ \\
\hline & SMIR & $0.06 \pm 0.008(45)$ & $0.12 \pm 0.006(100)$ & $0.16 \pm 0.01(64)$ & $79.73^{* * *}$ \\
\hline & Steps/min & $4.1 \pm 0.82(45)$ & $3.7 \pm 0.47(105)$ & $3.6 \pm 0.69(66)$ & $0.7^{\text {ns }}$ \\
\hline & FSI & $20.5 \pm 6.4(31)$ & $23.9 \pm 9(26)$ & $33.2 \pm 10.7$ (34) & $3.08^{\mathrm{ns}}$ \\
\hline \multirow[t]{6}{*}{ Zebra } & Bites/min & $20.3 \pm 1.8(38)$ & $12.7 \pm 0.5(121)$ & $10.6 \pm 0.54(108)$ & $107.75^{* * *}$ \\
\hline & Chews/min & $43.7 \pm 6.7(38)$ & $48.5 \pm 1.3(121)$ & $48.6 \pm 1.5(108)$ & $0.52^{\mathrm{ns}}$ \\
\hline & IIR & $7 \pm 0.6(38)$ & $8.3 \pm 0.34(121)$ & $9.7 \pm 0.5(108)$ & $3.9^{*}$ \\
\hline & SMIR & $0.12 \pm 0.01(38)$ & $0.14 \pm 0.01(121)$ & $0.16 \pm 0.01(108)$ & $3.8^{*}$ \\
\hline & Steps/min & $2.7 \pm 0.44(38)$ & $1.9 \pm 0.25(120)$ & $1.8 \pm 0.21(108)$ & $1.76^{\text {ns }}$ \\
\hline & FSI & $43.3 \pm 9.5(26)$ & $41.1 \pm 6.3(26)$ & $54.9 \pm 9.9(49)$ & $0.05^{\mathrm{ns}}$ \\
\hline
\end{tabular}

IIR, instantaneous intake rate $(\mathrm{g} / \mathrm{min}) ; \mathrm{SMIR}$, specific mass intake rate $(\mathrm{g} / \mathrm{min}$ per W0.75); $\mathrm{FSI}$, feeding station interval in seconds; $\mathrm{Cl}$, $95 \% \mathrm{confidence}$ interval; $n$, number of observations; ${ }^{*} p<.05,{ }^{* *} p<.01,{ }^{* * *} p<.001$; ns, not significant. 
impala maximized its intake by mostly foraging in tall swards. The ability of its small muzzle to select highly digestible grass parts as forage could have helped it choose leaves and avoid more fibrous stems while feeding in tall swards (Jarman \& Sinclair, 1979). In fact, Drescher, Heitkonig, Raats, and Prins (2006) suggested that in response to a decline in quality with increasing grass biomass, herbivores select smaller but higher quality bites within tall swards. Therefore, in order for impala to obtain adequate forage for its daily maintenance, it seems to practice a feeding strategy that maximizes intake in tall swards that are of comparatively lower quality but of higher biomass than short swards. Groom and Harris (2009) found out that wildebeest

TABLE 3 1-way ANOVA for differences in movement pattern variables between impala and zebra grazing on short, medium and tall swards. Sexes were taken together

\begin{tabular}{lllcl} 
Sward & Variable & Mean $\pm \mathrm{Cl}(n)$ & $\begin{array}{l}\text { Zebra } \\
\text { Mean } \pm \mathrm{Cl}(\boldsymbol{n})\end{array}$ & F-ratio \\
Short & Steps/min & $4.1 \pm 0.82(45)$ & $2.7 \pm 0.44(38)$ & $52.82^{* * *}$ \\
& FSI & $20.5 \pm 6.4(31)$ & $43.4 \pm 9.5(26)$ & $347.35^{* * *}$ \\
\multirow{2}{*}{ Medium } & Steps/min & $3.7 \pm 0.47(105)$ & $1.9 \pm 0.25(120)$ & $174.84^{* * *}$ \\
& FSI & $23.9 \pm 9(26)$ & $41.1 \pm 6.3(26)$ & $393.03^{* * *}$ \\
\multirow{2}{*}{ Tall } & Steps/min & $3.6 \pm 0.69(66)$ & $1.8 \pm 0.21(108)$ & $117.74^{* * *}$ \\
& FSI & $33.2 \pm 10.7(34)$ & $54.9 \pm 9.8(49)$ & $799.11^{* * *}$ \\
\hline
\end{tabular}

$\mathrm{FSI}$, feeding station interval in seconds; $\mathrm{Cl}, 95 \%$ confidence interval; $n$, number of observations; $* p<.05, * * p<.01, * * * p<.001$.
(Connochaetes taurinus) and zebra mostly grazed in patches of high grass biomass regardless of their quality during the dry season. In this case, they maximized their intake at the expense of quality which generally declines in savannah grasses during the dry season. This seems to have occurred during this study as a survival strategy for impala.

A similar effect of sward height on SMIR was observed in zebra having a significantly higher SMIR in tall than in short swards. Zebra being a large grazer might be more restricted by bite depth in short swards. Also being a hind gut fermenter, it can tolerate more fibrous forage typically found in tall swards because of its high gut through put and lack of a sieving mechanism for large food particles that delays food passage through the gut as in ruminants (Van Soest, Jeraci, Foose, Wrick, \& Ehle, 1983).

\subsection{Feeding station interval and stepping rate between impala and zebra}

Zebra had a significantly longer FSI and lower stepping rate in tall swards compared to impala. This is as predicted for zebra which is larger than impala and thus has higher daily maintenance requirements that require it to forage in tall swards longer to obtain adequate grass biomass for survival. Higher FSI and lower stepping rate coupled with highest SMIR in tall swards for both impala and zebra suggest that these herbivores utilized tall swards to a great extent.

TAB LE 4 2-way ANOVA for differences in foraging behaviour variables between male and female impala grazing on short, medium and tall swards

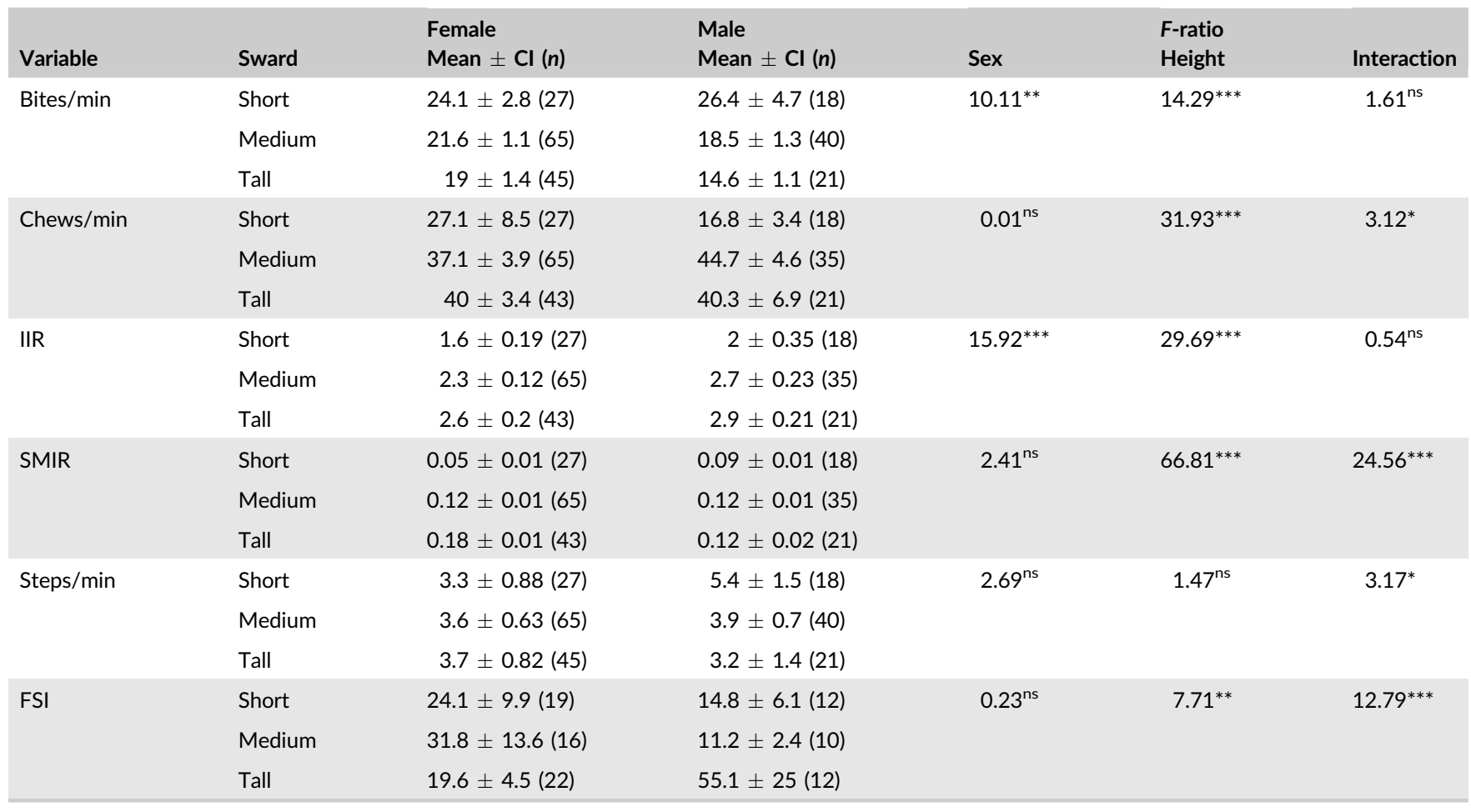

IIR, instantaneous intake rate (g/min); SMIR, specific mass intake rate (g/min per W0.75); $\mathrm{FSI}$, feeding station interval in seconds; $\mathrm{Cl}$, $95 \%$ confidence interval; $n$, number of observations; ns, not significant; *p $<.05, * * p<.01, * * * p .001$. 


\subsection{Effect of sex and sward height on specific mass intake rate in impala}

Specific mass intake rate differed with sex, but increased with sward height. Males had higher SMIR than females in short swards contrary to our prediction. However, both sexes had their highest SMIR in tall swards, supporting our earlier suggestion that tall swards provided maximum returns in terms of forage biomass. The pattern in which female and male impala move within patches while foraging can be used to explain the differences in their SMIR in tall swards. Males had a lower stepping rate and a longer FSI than females. Females on the other hand wandered more within different patches in tall swards resulting into their higher stepping rate, suggesting that they were feeding more selectively, to satisfy their higher metabolic requirements. This finding concurs with the predictions of the forage selection hypothesis (Main et al., 1996).

\section{5 | CONCLUSION}

Impala had a higher stepping rate compared to zebra while FSI for zebra was longer than for impala in tall swards. Zebra maximized their SMIR in tall swards and so did female and male impala; however, males had a lower stepping rate than females in tall swards. These findings demonstrate that foraging behaviour variables are influenced by grass swards of different height and that impala and zebra largely foraged on the same swards. Since the period of low rainfall is critical in the savannah in terms of reduced grass quality, this study further demonstrates that herbivores such as impala and zebra can maximize their forage intake in tall swards despite its lower quality as a trade-off among short and tall swards so as to obtain adequate forage for their maintenance. Tall swards are thus critical to the survival of impala and zebra and therefore should be actively managed in order to prevent them from bush encroachment which is a persistent problem in the study area.

\section{ACKNOWLEDGEMENTS}

We owe a debt of gratitude to Alison J. Bartlett and Michiel B. van Hasselt for their great field work in Naivasha, Kenya. We thank Kenya Wildlife Service for permission to conduct the study. This research was funded by the Netherlands Organisation for International Cooperation in Higher Education and Wageningen University to which we are grateful.

\section{REFERENCES}

Beekman, J. H., \& Prins, H. H. T. (1989). Feeding strategies of sedentary large herbivores in East Africa with emphasis on the African buffalo. African Journal of Ecology, 27, 129-147.

Black, J. L., \& Kenny, P. A. (1984). Factors affecting diet selection by sheep. II. Height and density of pasture. Australian Journal of Agricultural Research, 35, 551-563.

Chacon, E., \& Stobbs, T. H. (1976). Influence of progressive defoliation of a grass sward on the eating behaviour of cattle. Australian Journal of Agricultural Research, 27, 709-727.
Clutton-Brook, T. H., \& Harvey, P. H. (1983). The functional significance of variation in body size among mammals. Special Publication American Society Mammal, 7, 632-663.

Drescher, M., Heitkonig, I. M. A., Raats, J. G., \& Prins, H. H. T. (2006). The role of grass stems as structural foraging deterrents and their effects on the foraging behaviour of cattle. Applied Animal Behaviour Science, 101, 10-26.

Edwards, G. R., Parsons, A. J., Penning, P. D., \& Newman, J. A. (1995) Relationship between vegetation state and bite dimensions of sheep grazing contrasting plant species and its implications for intake and diet selection. Grass \& Forage Science, 50, 378-388.

Geist, V. (1974). On the relationship of social evolution and ecology in ungulates. American Zoologist, 14, 205-220.

Ginnett, T. F., \& Dimment, M. W. (1995). The functional response of herbivores: Analysis and test of a simple mechanistic model. Functional Ecology, 9, 376-384.

Groom, R., \& Harris, S. (2009). Factors affecting the distribution patterns of zebra and wildebeest in a resource-stressed environment. African Journal of Ecology, 48, 159-168.

Haltenorth, T., \& Diller, H. (1980). Mammals of Africa including Madagascar. Hong Kong: HarperCollins.

Illius, A. W., \& Gordon, I. J. (1987). The allometry of food intake in grazing ruminants. Journal of Animal Ecology, 56, 989-999.

Jarman, P. J. (1974). The social organisation of antelope in relation to their ecology. Behaviour, 48, 215-266.

Jarman, P. J., \& Sinclair, A. R. E. (1979). Feeding strategy and the pattern of resource partitioning in ungulates. In A. R. E. Sinclair \& M. NortonGriffiths (Eds.), Serengeti: Dynamics of an ecosystem (pp. 130-163). Chicago, IL: The University of Chicago Press.

Main, M. B., Weckerly, F. W., \& Bleich, V. C. (1996). Sexual segregation in ungulates: New directions for research. Journal of Mammalogy, 77, $449-461$.

Novellie, P. (1978). Comparison of the foraging strategies of blesbok and springbok on the Transvaal highveld. South African Journal of Wildlife Research, 8, 137-144.

Okello, M. M., Wishitemi, R. E. L., \& Muhoro, F. (2002). Forage intake rates and foraging efficiency of free-ranging zebra and impala. South African Journal of Wildlife Research, 32, 93-100.

Ombadi, A., Sudekum, K. H., \& Taube, F. (2001). Dynamics of changes in digestibility and feed intake by sheep of two ryegrass species during primary growth. Journal of Animal Physiology and Animal Nutrition, 85, 385-405.

Owen-Smith, N. (1982). Factors influencing the consumption of plant products by large herbivores. In B. J. Huntly, \& B. H. Walker (Eds.), Ecology of tropical savannas. Berlin: Springer-Verlag.

Owen-Smith, N., Fryxell, J. M., \& Merrill, E. H. (2010). Foraging theory upscaled: The behavioural ecology of herbivore movement. Philosophical Transactions of the Royal Society of London. Series B, Biological Sciences, 365, 2267-2278.

Parson, A. J., Thornley, J. H. M., Newman, J., \& Penning, P. D. (1994). A mechanistic model of some physical determinants of intake rate and diet selection in a two species temperate grassland sward. Functional Ecology, 8, 187-204.

Prins, H. H. T., \& Olff, H. (1998). Species richness of African grazer assemblages: Towards a functional explanation. In D. M. Newbery, H. H. T. Prins \& N. D. Brown (Eds.), Dynamics of tropical communities (pp. 449-490). Oxford: Blackwell Science.

Skinner, J. D., \& Smithers, R. H. N. (1990). The mammals of Southern African subregion. Pretoria: University of Pretoria.

Spalinger, D. E., \& Hobbs, M. T. (1992). Mechanisms of foraging in mammalian herbivores; new models of functional response. American Naturalist, 140, 325-348.

Stobbs, T. H. (1973). The effect of plant structure on the intake of tropical pastures. I: Variation in the bite size of grazing cattle. Australian Journal of Agricultural Research, 24, 809-819. 
Ungar, E. D., \& Noy-Meir, I. (1988). Herbage intake in relation to availability and sward structure: Grazing processes and optimal foraging. Journal of Applied Ecology, 25, 1045-1062.

Van Soest, P. J., Jeraci, J., Foose, K., Wrick, K., \& Ehle, F. (1983). Comparative fermentation of fibre in man and other animals. In G. Wallace \& L. Bells (Eds.), Fibre in human an Atzinzal nutrition (pp. 75-80). Wellington: Royal Society of New Zealand.

Wikstrom, M. L., Robbins, C. T., Hanley, T. A., Spalinger, D. E., \& Parish, S. M. (1984). Food intake and foraging energetics of elk and mule deer. Journal of Wildlife Management, 48, 1285-1301.
How to cite this article: Mwasi SM, Heitkönig IMA, Van

Wieren SE, Prins HHT. Foraging behaviour of wild impala (Aepyceros melampus) and Burchell's zebra (Equus burchelli) in relation to sward height. Afr J Ecol. 2018;56:334-341.

https://doi.org/10.1111/aje.12459 